Canadian Studies in Population, Vol. 30(1), 2003, pp. 75-115

\title{
Aboriginal Population of Canada: Growth Dynamics under Conditions of Encounter of Civilisations
}

\author{
Anatole Romaniuc \\ Adjunct Professor \\ Department of Sociology \\ University of Alberta
}

\begin{abstract}
This paper endeavours to capture the broad configuration of demographic evolution of the Aboriginal peoples of Canada from the early contacts with Europeans to the present. The main stages thereof are identified and the underlying factors explored, against the historical background of Aboriginal and European civilisations' encounter. While taking stock of the past, the paper takes a glimpse into the future. It concludes with a review of demographicallydriven policy issues that the First Nations are likely to confront as they step into the 21 s Century.
\end{abstract}

Key Words: Aboriginal population, First Nations, population policy 
Anatole Romaniuc

\section{Résumé}

L'article vise à saisir les contours les plus significatifs de l'évolution démographique des populations autochtones depuis l'ouverture du Canada à la colonisation européenne. Les principales étapes sont identifiées et les facteurs sous-jacents explorés, dans la perspective des contacts des civilisations européenne et autochtone. Tout en retraçant le passé, l'auteur jette un regard sur l'avenir. L'exposé conclut avec un aperçu des questions politiques, engendrées par le développement démographique, que les premières nations de ce pays pourraient être amenées à affronter à l'horizon du 21e siècle.

Mony-clés: Aboriginal population, First Nations, population policy

\section{Introduction}

The demographic literature on Canada's Aboriginal peoples is fairly extensive, but studies that take a long historical view are few and by now somewhat dated. ${ }^{1}$ This paper endeavours to capture the broad configuration of the Aboriginal peoples demographic evolution from the early contacts with the Europeans to the present. The main stages thereof are identified, and the underlying factors explored. While taking stock of the past and present we will venture a glimpse into the future. The paper winds-up with an overview of the demographically-driven policy issues that emerge for Canada's First Nations as they step into the $21^{\text {st }}$ century.

fortune of the Aboriginal peoples has taken dramatic twists from near extinction to impressive recovery. However, their resilience against superior forces, their vitality to rebound under the most adverse conditions, and the promises of the future, should not blind us from recognising the inherent vulnerability of a minority numerically weaker, fragmented and widely dispersed, still contending with many attributes of an underprivileged class of people.

As we proceed with the analysis of the Aboriginal peoples' major demographic shifts over time, we will come to recognise, in its variegated manifestations, the potency of culture in shaping reproductive behaviours. We shall also take cognisance of the fact that, unlike immigrant minorities, they represent a sui 


\section{Aboriginal Population of Canada: \\ Growth Dynamics under Conditions of Encounter of Civilisations}

generis historical entity, struggling for the recognition and preservation of their identity and special political status. Canada's Aboriginal minority may be looked upon as part of a wider community of Indigenous minorities across North America, Siberia (Bobrick 1992) and the world, including the Aborigines of Australia (Grey 1990) and the Maori of New Zealand (Pool 1991). They form what some call the 'Fourth World'.

The Native peoples' demographic evolution can best be comprehended when examined against the historical background of the encounter between the Aboriginal and European civilisations. This encounter is to be understood as a dynamic process that is still unfolding, and not as a dated event. A brief sketch of this historical encounter is in order.

The European colonisation of the vast territory that is today's Canada was piecemeal, spanning over three centuries or so. As late as 1793, on his northeast exploratory voyage along the river that bears his name, Mackenzie reports that the Indians he met on his way "[...] had heard, indeed, of white men, but this was the first time that they had ever seen a human being of a complexion different from their own" (1911:89, Vol. II). The two civilisations were at very different technological and economic stages of development. The ultimate takeover of Canada by the Europeans was the consecration of "[the] superiority of the gun over the bow and arrow, of the steel axe over the stone axe, of the steel plough over the stone hoe or digging-stick [...]" (Sametz 1965: 33).

Historically, the relations between Natives and Europeans have taken various turns. From the outset and well into the 19th century, the fur trade (Ray 1984) dominated the encounter, in terms of economics. Eventually it led to the depletion of game, which further upset the precarious balance between nature and population. Capitalism largely transformed the country's economics and demographics as European immigration reached new heights. However, unlike the long period of partnership that characterised the fur trade, the Natives hardly played a role in the emerging European society. They were reduced to passive, helpless, and often troubled onlookers of what was happening around them. By contrast, the advent of the welfare economy in the wake of World War II had a salutary effect on their demographic fortune.

Politically, too, this encounter underwent significant shifts over time. In the earlier days the relation between the two communities, though occasionally marred by armed conflict, was one of coexistence and accommodation - in many ways symbiotic. However, as the colonial power took hold, the lot of Indigenous inhabitants turned into one of political and economic dependence the government tightened its control over their destiny and aimed for their ultimate assimilation. The policy after World War II emphasised integration, 
and, as of late, self-government is on the policy agenda. We shall see how these and similar economic and political factors played out to influence the demographic behaviour of Native peoples.

The main demographic stages in the historical evolution of the Aboriginal peoples can be stated succinctly. After what was in the long-run most likely a quasi-stationary demographic state, punctuated by the ups and downs due to natural disasters and inter-tribal warfare, the Aboriginal peoples underwent an almost three-century-long depopulation with the coming of the Europeans. A stabilization and slow recovery came about at the turn of the 20th century. After World War II a remarkably dynamic growth came out of a rapid decline in mortality, on the one hand, and an increase in natural fertility, on the other. The cycle of natural fertility increase associated with the early modernisation processes is one of the remarkable features of the Aboriginals' more recent demographic experience. They entered demographic transition from a traditional high to a modern low fertility almost a century after Canadians of European stock. Today the transition is well underway, but they still have some way to go before reaching parity with the latter.

With these preliminary remarks as to the overall historical setting in which Aboriginal peoples have evolved demographically, we should examine the various demographic stages just outlined, beginning with early contact, the most controversial period.

\section{Demographic Regime Of The Pre-And Early Contact Era: A Precarious Demographic Equilibrium}

The size of Canada's Native population upon the arrival of the Europeans has been and still is a hotly disputed subject. Emotions, ideologies and self-serving interests sometimes colour the discussion thereof. ${ }^{2}$ In the words of the historian Olive Patricia Dickason (1992: 27):

"The earliest European accounts of the New World all spoke of the 'great multitudes of people'; it was later, when colonisation was gaining momentum, that the large stretches of territories were found unoccupied, and the notion of 'empty continent' gained currency."

Notwithstanding all the attempts using a variety of estimation techniques, the numbers cannot be ascertained with any degree of plausibility. We are left with a wide range of guess-estimates. Thus, Thoronton (1987: 242) has estimated a population in excess of 2 million "north of the United States". To arrive at this figure, he applied the 'standard hemispheric depopulation ratio', which Dubyns assumed to be 20 to 1 (1966: 414). 


\section{Aboriginal Population of Canada: \\ Growth Dynamics under Conditions of Encounter of Civilisations}

Other researchers have produced much lower figures. Mooney (1928) estimated the Aboriginal population of America north of the Rio Grande to be 1.2 million, and that of Canada to be close to 200,000. His calculation relied on historical material of individual tribes and by adding the tribe-by-tribe estimates. Similar figures were advanced by Kroeber (1963), who resorted to a technique that combined historical records and estimates of the carrying capacity of the relatively homogeneous natural areas established for that purpose. Later, Hubert Charbonneau (1984) put forth a ballpark figure of 300,000 for Canada's Aboriginal population in the early contact era. He derived this figure by upwardly adjusting by $40 \%$ the estimates available for the tribes known to have existed at that time, to make allowances for omissions and understatements.

None of these estimates has an empirical base solid enough to afford scientific credibility. What can be said with near certainty, however, is that a significantly greater number of people inhabited this country upon the coming of the Europeans than the numbers that were subsequently revealed - around 100,000 by the first national Censuses, taken in the late 19th and early 20th centuries.

Uncertain as we are of the population numbers, we can nevertheless piece together a picture of what most likely was in very broad terms the demographic regime in these earlier days of contacts. To this end, one may turn to the explorers and pioneers' accounts. Although fleeting and space-confined by necessity, and admittedly sometimes biased, I found these accounts highly edifying on Aboriginal settlement patterns, living conditions, the state of technology, political organisation, family and marriage customs, and sexual mores. Also, one can work inferentially from certain factors known to have governed the life of Aboriginal inhabitants. By combining these two approaches one can arrive at an approximation of the demographic regime, if not at the actual population figures.

In what follows I shall review the documentary evidence and inferences derived form factors likely to have controlled population growth for the early contact era. There are four sets of such factors - biotic environment, technology, living or subsistence conditions, and political organisation.

Aboriginal inhabitants of Canada contended with harsh climatic conditions for most of the year. They had to hunt, trap, fish and gather for sustenance. Large tracts of land were required for bands in search of game. The state of technology was that of the late Stone Age. Stone axes, digging sticks or hoes with blades made from shell were the tools used in agriculture and housekeeping. There was no practical application of the wheel to transportation or manufacturing. The only domestic animal was the dog, which was useful for transportation and 
hunting but of little value for either food or clothing (Jenness, 1977).

Clearly, under such biotic and technological conditions, the carrying capacity of the land and the productivity of work must have been exceedingly low. Widely dispersed nomadic or semi-nomadic settlements which were reported by the early explorers, missionaries and pioneers, stand out as the dominant landscape in those early days of contact. In his exploration of the St. Lawrence and the Great Lakes, Chevalier de La Salle speaks of the 'unbroken wilderness' and 'dreadful conditions of savages' (Abbott 1898: 92). Mackenzie (1911: 343, Vol. II) makes similar remarks on the whole region north of the St. Lawrence and far into Hudson's Bay: "[...] a vast area inhabited only by a few savages, whose numbers are proportionate to the scantiness of the soil [...]."

Contrasting with this picture of a widely predominant demographic void are two better populated regions: one is in the west, on the Pacific shore with its abundant sea resources and relatively advanced storage and preservation technology; the other region coincides with the semi-agricultural land along the St. Lawrence River.

But even in the latter region the numbers were not large. The allegedly 'very populous,' sedentary Huron nation which, as father Paul le Jeune reports in The Jesuit Relations, presented "attractive prospects for missionary work to spread the word of Gospel," turned out to be 12,000 when the census was taken in 1639 (Mealing 1969: viii). The mighty Iroquois nations that occupied relatively large and fertile lands overarching the present-day US/Canada boarder were estimated at 38,000 according to Kroeber (1939) and 56,000 according to Price (1979: 44). And, the Seneca nation, "the most numerous of all Iroquois counted about a thousand or twelve hundred men capable of bearing arms" (Kellogg 1917: 180). The strength of the invading armies, as described in many early reports, were in the hundreds, rarely in the thousands and never in the tens of thousands - an indication of a rather limited demographic capacity to raise armies even among such powerful, warlike nations as the Iroquois.

As one moves southward, deeper into today's United States, to climatically more hospitable lands, the landscape of settlements appears to be more cheerful. Samuel de Champlain remarks: "Pour ce qui est de midi de la grande revière [Saint Laurent] elle est fort peuplée, et beaucoup plus que le coté du nord" (Dumont 1962: 190). The impression conveyed by the explorers' reports is that of a settlement pattern of somewhat larger clusters of ethno-cultural communities that were separated by considerable stretches of niemandsland, as it were, to ensure a safe distance in case of unexpected attacks by feuding tribes.

Reports by pioneers also abound with references to exceedingly poor living conditions and the lack of the most elementary notions of hygiene and sanitation. Thus father Marquette, a member of Chevalier de La Salle's 


\section{Aboriginal Population of Canada: \\ Growth Dynamics under Conditions of Encounter of Civilisations}

expedition, was struck by the habitat of a cluster of Indian wigwams several leagues from the mouth of the Chicago River. "The savages were poor, but few in number, and their abodes comfortless" (Abbott 1898: 62). Likewise of the Miami tribe it is reported that "a few wretched wigwams were scattered over snow-white plains, where poverty, destitution, and repulsive social habits reigned, such as perhaps never witnessed in civilised life" (p. 63). The depressingly poor state of the housing staggered many explorers and led them to lament the suffering they had to endure while lodging with their Indigenous hosts. "You cannot stand upright in this house, as much on the account of the low roof as of the suffocating smoke"; "[...] a martyrdom. It almost killed me," bewailed father Paul le Jeune in The Jesuits Relations (Mealing: 32/33). Blindness and coughing, for example, were often observed. Note, in passing, that poor housing conditions are the reality for Aboriginal peoples of the present day.

As much as these and similar observations may shock the sensibility of modern man - Aboriginal and non-Aboriginal alike - those were the conditions of the Neolithic man generally and not just of the Canadian Natives. The Neolithic man was living in a precarious, volatile equilibrium with his natural environment. Under such conditions one would expect the subsistence and environment-related causes of deaths to be widely prevalent. Reports by explorers, missionaries and early administrator frequently mention famine and death from starvation. Hunting accidents, drowning, exposure to frost, and food poisoning to name but a few environmental and occupational hazards, as well as the dangers associated with the nomadic mode of life, were significant causes of mortality. Note that some of these causes, like poisoning and violent accidents, are still prevalent today. Infanticide and the abandonment of the old and impaired (which to some extent have survived to more recent times) are known to have been practised to varying degrees as a survival strategy under continuous ecological pressure (Balikci 1973). ${ }^{4}$

However compelling the subsistence thesis - the scarcity of resources and recurrent famines that kept in check the growth of population - it might not in itself be sufficient to explain the under-population of early North America. At best it may attest to the truth of the precarious living conditions in the northern regions. But how then does one explain the under-population of the regions south of the border with all their natural beauty, exuberance and abundance which caught the eye and admiration of explorers? "These prairies are capable of sustaining immense population" (p. 265) "[...] fields are full of all kinds of game [...]". "Peach trees are so loaded in the gardens of the Indians, that they have to prop up the branches". These are father Membré's notes, another companion of La Salle's journey along the majestic Mississippi River in 1679 (Abbott 1898: 264/65) . 
It follows that neither of the three population-depressing factors - biotic environment, technology and subsistence or living conditions - offers a sufficient explanation of the demographic regime of under-population which in all likelihood prevailed in Canada in the pre-or early contact era. We are left with the one remaining population-related factor: the weakness of the sociopolitical structure and organisation. The prevalent political organisation was the band or tribe, more rarely chiefdom. As such it was ill equipped to secure internal peace and to protect the tribe from outside predators. In their writings missionaries and administrators frequently mentioned blood revenges and feuds. Public justice was either non-existent or ineffective. Inter-tribal war was endemic, typical of most prehistoric stateless communities: a kind of Hobbesian state of 'war of all against all'. Mackenzie remarks, "There is no regular government among them [....] no sufficient communication to defend themselves against an invading enemy, to whom they fall an easy prey" (1911: 322 , vol. II). The narratives of explorers and missionaries abound with warfare horror stories. "Around the lovely shores of Lake Peoria there had been seventeen flourishing Indian villages. These were all destroyed, in awful scenes of conflagration and massacre. The survivors fled beyond the Mississippi, six hundred miles from their desolated homes. And even to these regions the ferocious Iroquois pursued them, thirsting for blood and scalps" (Abbott, 1898: 219).

Needless to say, the history of humankind is full of horrors of warfare, and no one should point the finger at Aboriginal peoples as the culprits of such abominations. But what sets the Neolithic society apart is its narrow-based political organisation, if any, and the nature of the warfare it waged. Because of the lack of larger stable state structures, the victorious parties were unable to integrate the vanquished tribes and thus increase their population and extend their territory. Such practices as the adoption of war prisoners or their integration into the tribe, even in an inferior social status as slaves, were limited. The nature of the warfare itself had its peculiarities. Rather than a means for territorial and demographic aggrandisement, war seems to have been an end in itself, a kind of self-perpetuating culture (Kroeber, 1963; Farb, 1972). Preventive strife was a self-preservation strategy, according to Kroeber the wellknown American anthropologist. "The group that tried to shift its value from war to peace was almost certainly doomed to early extinction" (p.148). He makes the case, convincingly in my view, that the main cause of the underpopulation of North America is to be found in the culture, meaning the warfare culture, rather than in its subsistence resources. Speaking of Eastern American agriculturists, he argues that any surplus in wealth only increased the potential for war, but that "war kept the population down to the point where more agriculture was not needed" (p. 149), so the process became a vicious circle. 


\section{Aboriginal Population of Canada: \\ Growth Dynamics under Conditions of Encounter of Civilisations}

We have dealt so far with what in Malthusian parlance is called the "negative checks' on the population, i.e. mortality, whether natural or man-made. Let's turn now to fertility, the other component of natural population growth.

The birth rate was probably high, as in any traditional society, to offset high mortality. But it does not seem to have been high enough to secure the longterm growth of the population. Explorers and early pioneers were unimpressed by the prolificity of Indian families. They were struck by the small number of offspring, and the frequency of barrenness among Native women. Father Gabriel Sagard (1969), in his voyage in 1623 through the Huron lands, offers illuminating observations on the state of both mores and childbearing. Though women seem to desire many children for their old age, they are not as prolific as one would expect: "[...] les femmes n'y sont pas si fécondes que par deçà: peutêtre tant à cause de leur lubricité, que du choix de tant d'hommes" (p. 111). Both Samuel de Champlain and Jean Talon made similar observations about tribes inhabiting the St. Lawrence. While some of these impressions may no doubt confound high child mortality, i.e. the small number of surviving offspring, with the low fertility, some of the explanations given are perfectly plausible.

First and foremost, due to the absence of animal milk or equivalent natural substitutes, mothers breast-fed their children over a long duration, and this in turn tended to depress fecundity and space pregnancies further apart. The delaying effects of breast-feeding on the resumption of ovulation, and, hence, on pregnancy, is well-documented in demographic literature (Romaniuc, 1981).

Second, there were certain pregnancy impairment causes that could best be subsumed under the label ecological hardship. Malnutrition, not to speak of outright sporadic starvation, poor hygiene, and accidents due to the nomadic life in a harsh long winter habitat may have delayed conception and caused pregnant women to miscarry or abort. Jean Talon, long-time administrator of French Canada and a keen observer of Indigenous lives, in an apparent comparison to French colonists in his Mémoire, refers to Native women's barrenness, protracted nursing and hard work: "Il n'en est pas de même des sauvages dont les femmes sont assez stériles, soit que le grand travail auquel elles sont obligées retard leur portée, soit qu'elles nourrissent trop longtemps leurs enfants à leur lait" (Talon 1967: 355). Similar views were later echoed by Alexander Mackenzie in his Voyage, a book about his journey through north-western Canada: "The women are not very prolific: a circumstance which may be attributed in a great measure, to the hardships that they suffer, for except a few small dogs, they alone perform that labour which is allotted to beasts in other countries" (1911: 23/24, Vol. II). 
Third, there are those factors that can be categorised under conjugal instability and promiscuity, both of which may delay pregnancy. Father Gabriel Sagard, like many other observers of the early and later contact period, makes the case of a rather fluid notion of marriage among some Native tribes. Regarding the Hurons he observes, "Plusieurs jeunes hommes, au lieu de se marier, ont souvant les filles à pot et feu, qu'ils appellent non-femmes, ekenhona, parce que la cérémonie du mariage n'en a point été faite, mais asqua, c'est- à-dire compagne ou plutôt concubine. Et ils vivent ensemble pour autant de temps qu'il leur plait, sans que cela empeche le jeune homme et la fille d'aller voir parfois leurs autres amis et amies librement et sans craindre de reproche ni blame" (Sagard 1969: 106). He goes on to point out the promiscuity in the Huron society: "[...] et les jeunes hommes de Canada et particulièrement du pays de nos Hurons, sont toujours en licence de s'adonner au mal sitôt qu'ils peuvent, et les jeunes filles de se prostituer sitôt qu'elles sont capables" (p.105/6). In his Voyage Mackenzie also mentions the rather lax attitudes toward extramarital relations, notwithstanding the severe penalties women may have had to endure for their infidelity at the hand of jealous men. "Chastity is not considered as a necessary virtue [...]". "[...] it seldom happens that a woman is without her favourite, who, in the absence of the husband, exacts the same submission, and practices the same tyranny" (1898: 310, Vol.2).

I found no specific references to sexually transmitted diseases in the earlier explorers' reports. But this does not mean there were none, given the rather lax sexual mores reported for some tribes. The quote above from Gabriel Sagard (1969: 111) - "Les femmes n'y sont pas si fécondes...peut-être tant à cause de leur lubricité, que du choix de tant d'hommes" - points out the cause of the problem. Note that syphilis among some tribes, particularly on the west coast, was reported later and is suspected to have been imported by European sailors.

The Native women seem to have reverted to abortion, the oldest practice to limit the offspring. "Abortions were frequent," according to The Jesuit Relations (Thwaites, 1899:257, Vol. I). The willingness to artificially terminate the pregnancy and/or to put an infant daughter to death immediately after birth can be attributed to harsh economic conditions and women's low status. "[...T]hey often sought to escape the added burdens of maternity, especially in seasons of want, by the twin practice of pre-natal abortion and infanticide," notes Diamond Jenness (1977: 52). As many primitive populations of the world, the Aboriginal peoples may have known and actually practised some forms of contraception (Vogel, 1970), but more likely occasionally than systematically as a means of birth control. Nor is the effectiveness of these practices borne out conclusively by various studies.

All these biological and cultural factors merged to produce a reproductive regime that can be qualified as reproductive sub-optimality. In laymen's terms this means that reproduction in those early days fell short of potentials and that the fertility rate was in the lower range of the natural fertility rates observed across 


\section{Aboriginal Population of Canada: \\ Growth Dynamics under Conditions of Encounter of Civilisations}

a wide array of pre-modern societies. Again as in the case of excessive mortality, there is, seemingly, a concordance between what the explorers and pioneers observed and what can be inferred in regard to childbearing from the prevailing living conditions.

I drew a rather grim picture, some would say unkind, of Aboriginal peoples' lives in those bygone days. But those were more than likely the conditions of the Neolithic man wherever he has lived, in America, Europe or elsewhere. The demographic regime was that of a population in precarious equilibrium with its natural environment. Mortality fluctuated widely due to the hazards of nature and endemic intertribal warfare. Fertility might not have been high enough to offset the excess of deaths, and to insure a sustained population growth. For brevity of expression, the prevailing demographic regime, when viewed in the long haul and at aggregate level, may best be called the regime of precariously stationary population.

\section{Collapse of Demographic Equilibrium and Depopulation}

The conquest of Canada by the French, followed by the British, upset the precarious, traditional demographic equilibrium. A number of factors combined to set off the spiral of depopulation as the conquest took hold and expanded. There are those that affected health and mortality directly, those that adversely modified man's relation to his natural environment, those that caused inter-tribal warfare, and finally, those that were responsible for social disorganisation.

The single most important factor in the Native peoples' demographic demise was the introduction of new contagious diseases by European colonists. Measles, scarlet fever, diphtheria, chicken-pox, smallpox, typhus, typhoid fever, malaria, yellow fever and possibly tuberculosis were some of the diseases brought in by the Europeans. These diseases were all the more deadly as the host population lacked natural immunity. Nor did they occur at a single point in time, but were recurrent over a protracted time - probably over three centuries - following the opening of Canada to European colonisation. The spread of various diseases took epidemic proportions and decimated entire tribes. Nor were these diseases limited to the contact areas, as they often travelled faster, well ahead of the white man's advances. Noble David Cook (1998) may be overstating the case when he attributes the conquest of the Americas to the epidemics of infectious diseases imported by Europeans "[these] diseases conquered the Americas before the sword could be unsheathed" - but he is not very far from the truth. Smallpox was by far the greatest killer until immunisation was introduced late in the 19th century. According to John Heagerty's Four Centuries of Medical History in Canada 
(1928: 65), "[t]here is little doubt that smallpox was one of the chief factors in the extermination of the red man." It has even been alleged that smallpox might have been used as germ warfare against the Indians. At least one case was documented which involved a stratagem offered by Sir Jeffery Amherst to Col. Henry Bouquet in his 1763campaign against the Indians. "Could it not be contrived to send the small-pox among these disaffected tribes of Indians? We must on this occasion use every stratagem in our power to reduce them" (After Heagerty 1928: 43). The scourge was so feared that the menace alone of letting it loose could bring certain tribes into submission. According to John Heagerty, "The most dreadful epidemic of small-pox in the history of Canada was that of the years 1755 to $1757 .$. "; when "all activities, even war which was being constantly waged, ceased" (p. 39).

The epidemics, and again most conspicuously the small-pox epidemics, impacted Aboriginal tribes, not only in terms of their demographics but also in terms of the politics vis-à-vis the advancing European power and the intertribal power struggles. Clark Wissler (1936:19) goes as far as to argue that epidemics had their hand in the redrawing of the ethnic map: "it is possible[...] that the small-pox broke the power of the Gros Ventre in 1780, giving the Assiniboin a chance to dominate and that when the latter fell victims to the disease in 1838 , the Cree profited thereby reaching their peak in numbers about 1860." In turn, "the extinction of the buffalo around 1880 should have effectively checked Cree expansion."

The introduction of firearms and horses to the Canadian prairies, coupled with the expansion of the fur trade, significantly modified the relationship between the Natives and their natural habitat. At first these technological novelties had beneficial results in that they enhanced man's control over the natural resources and made it easier to acquire food. Through the fur trade, new commodities, particularly household items, made their way into the Native lifestyle adding a modicum of comfort. It has even been argued that the arrival of the horse helped to alleviate the hardships of women, on whose shoulders traditionally befell the heavy task of carriers in the frequent wanderings of peoples prone to nomadism.

But the victory over the natural surroundings and the benefits derived from the fur trade were short-lived. It was a Pyrrhic victory. It did not take long for the acquired marginal improvement in material well-being (and to some extent political independence) to evolve into economic hardship and in some places outright disaster. With the introduction of the gun and the horse and the evergrowing commercialisation of fur and the wasteful slaughter of large animals, the land was virtually stripped of its food and fur-bearing game. The caribou in the east and the sea otter on the north-western coast almost vanished. Commercial overkill of whales and walruses led in the 1870s to widespread starvation in the Arctic and sub-Arctic. Buffalo were particularly affected. The 


\section{Aboriginal Population of Canada: \\ Growth Dynamics under Conditions of Encounter of Civilisations}

saga of their indiscriminate mass slaughter is well known. The buffalo, which inhabited the vast regions of the plains in America west of the Mississippi River and in western Canada (estimated at about eighty million at early contact with the Europeans), was the Plain Indians' mainstay of life. "To the Plain Indians, the animal [buffalo] furnished a preponderantly large proportion of their daily necessities in food, together with clothing, housing, fuel, tools, weapons..." (Roe, 1951: 197). After 1830, the era of 'systematic destruction', which was triggered and sustained by the fur trade, culminated in "the shocking holocausts [of the buffalo] of 1870-74 in the south and in the final one of 188093 in the northern habitat" (Roe, 1951:191). During the winter of 1886-87, remarks Horaday (after Roe, p. 484), "destitution and actual starvation prevailed to an alarming extent among certain tribes in the Northwest Territory who once lived bountifully on the buffalo."

At the same time their economic base was severely curtailed as a result of land expropriation by the Crown and occupation by settlers of their hunting and food gathering grounds. Eventually these combined sets of factors led to their pauperisation and ultimately to their economic and political dependence, confinement to reserves and handouts by the state.

Warfare had not subsided. On the contrary, caught up in the French and British colonial power rivalries, inter-tribal conflicts grew in scope and, due to firearms, in destructiveness. The expansion of the fur trade and the depletion of game led to frequent battles over hunting grounds. Horses enabled warfare to be carried further afield where foot soldiers could not have ventured.

There can be little doubt that wars and epidemics had a direct or indirect debilitating effect on childbearing as well. The introduction of alcohol also had serious consequences, and not only in terms of health. Its deleterious effects on social cohesion, from community and family disruption to violence, are well documented. It still remains a potent factor in social disorganisation today. The same can be said for actions performed to 'civilise savages', to the extent they may have contributed to the weakening of the traditions that kept the group together.

Fragments of statistics for a few tribes, taken from Wissler's article (1936), highlight the changes in population size from the late 18th to the late 19th centuries. Thus the Assiniboin population (in Canada and South of its borders) of 10,000 in 1780 dwindled to 4,140 by 1884 . The Gros Ventre and Blackfoot population in both the US and Canada was 18,700 in 1780 but had sunk to 9,260 by 1884 . And the population of the north-western Plains Indians, once 28,700 at around 1780 , shrunk to 15,434 by 1899 . As questionable as these figures may seem to the sceptical demographer's eye, they are nevertheless 
indicative of the severity of the Natives' population implosion. And they are consistent with what demographers have been saying all along about the collapse of the Aboriginal population following the conquest. Of this implosion there is general agreement among scholars that since the opening of Canada to the Europeans and until around 1900, the excess of deaths over births has been the rule rather than the exception. Hubert Charbonneau (1984) speaks of three centuries of Amerindian depopulation.

\section{Demographic Stabilization and Recovery}

The process of depopulation reached its nadir at the turn of the 20th century and a slow journey towards demographic recovery began thereafter. Underlying this at first sluggish but predictable recovery is the progressive control over, and elimination of, the very same causes which were responsible for the depopulation.

First and foremost, the fight against the epidemics took a turn for the better. Inoculation against smallpox was intermittently and locally applied early and routinely late in the 19th century. It is also likely that with time the Indians acquired some natural immunity against imported contagious diseases. The inbreeding with Europeans probably contributed to this natural resistance as well, according to Charbonneau (1984). But many other infectious diseases, particularly influenza, continued to wreak havoc on their health. Tuberculosis remained pervasive, often fatal, until the advent of penicillin and antibiotics shortly after World War II.

Then Pax-Canadiana brought an end to inter-tribal warfare, which was one of the major causes of the under-population of North America. The last inter-tribal battle of importance was fought in 1870 at the Oldman River between the Blackfoot and the Cree. Owing to the government relief policy, famines and starvation subsided.

These changes for the better caused a moderate but steady population increase. According to statistics that the government began collecting in the second half of the 19th century, the Indian population, estimated at 107,000 in 1901, rose to 133,000 in 1931 and to 166,000 in 1951 or an average annual increase of 0.73 and 1.11 percent over the two periods, respectively. One cannot be certain whether this increase reflects demographic gains, better enumeration or both. Inferentially, however, one can well argue that the Native peoples were at long last climbing out of their long-drawn demographic malaise. Though epidemics subsided, mortality was still high. Fertility, which probably remained at its traditional moderately high level, was sufficient to offset mortality and even to generate a modest rate of natural population growth. 


\section{Aboriginal Population of Canada: \\ Growth Dynamics under Conditions of Encounter of Civilisations}

However, there is more to these developments than meets the eye. The late 19th century witnessed a string of events that was bound to determine the fate of the Aboriginal peoples as a distinct cultural and political entity for decades to come. The jurisdictional transfer in 1867 of Rupert's land and the North-Western territories - a huge mass of land that was home to numerous Indigenous tribes, between the Hudson Bay Company and the Canadian Confederation - was a watershed not only in Canada's history but in Native peoples' history as well. The Native people, who up to that point in time enjoyed the practically uninhibited freedom to pursue their traditional activities and their way of governance, were brought under Canadian rule. The construction of the Canadian Pacific Railway, linking eastern and western Canada, was a powerful impetus to the unity of the country and to its economic expansion and massive westward white settlement. Yet at the same time the encroachments on Native lands by white settlers and the intervention by Canadian authorities in matters of local governance unleashed recurrent political tensions. The uprisings lead by the Métis Louis Riel in 1867/70 and in 1885 can be seen as the last stand of a nascent nation that was committed to preserving its traditional ways of life against the advancing frontiers of an 'alien civilisation' (Stanley 1960: 49). Of historical importance was the adoption of the Indian Act in 1876. Indians acquired a special political status in Confederation, and this was bound to have far reaching political, social and economic consequences. The policy concerning reservations, whereby Indians were given tracts of land for their exclusive use, was pursued with greater vigour. The Crown treaties which compensated them in cash and in kind in exchange for their renunciating their ancestral lands, were also pressed forward. Segregation in the form of reservations, along with many other restrictive measures, went hand-in-hand with attempts to assimilate them into the dominant society. Banning certain rituals and traditions, replacing traditional chiefs with elected chiefs who reported directly to the white administration, and removing children from their parents for the duration of their education are instances of this assimilative effort.

The offshoot of these policies was the tightening control over Indian life. Amerindians, in the words of the historian Dickason, became " the most regulated peoples in Canada [...]; their lives would be interfered with at every turn, down to the personal level" (1992: 283). Economically, in the parlance of the time, they were 'wards' of the government. Thus the dependency mentality that was to develop into a durable trait was born and, as we shall see, was bound to affect their procreative behaviour, and even, to some extent, impede progress in health. Then again, government assisted projects to steer Natives away from traditional activities were deemed expedient as a matter of policy. With the depletion of game and the encroachment by white settlers on their 
hunting grounds, Natives could no longer rely on nature for sustenance.

History is replete with twists and ironies. Not infrequently actions taken with a particular purpose in mind unwittingly defeat their own purpose. Such was the case with the reservation and treaty policies. Although intended as a means of political and economic control over the Indigenous peoples to promote their ultimate assimilation, these policies turned into a means of securing their survival as a distinct society. They helped the First Nations to assert their political identity, and in conjunction with other developments that we shall probe next, they also helped to bring about a remarkable demographic growth.

\section{Post-War Demographic Acceleration: Rise In Natural Fertility}

The developments above, auspicious in many ways, received a new impetus in the aftermath of World War II with the rise of the welfare economy in Canada.

The shift from a subsistence and trade-based economy to a wage and welfare economy led Indians to relinquish much of their nomadic way of life. The policy of resettlement was aimed at consolidating small settlements into ones which were larger, more stable, and better equipped with medical and social services, housing and schools, and some on-site employment opportunities. Increasingly, Natives relied on local commercial stores for their food rather than on what they used to produce themselves. This brought greater variety (and maybe quality) to their calorie intake, but, by the same token, increased their dependency on wage and government subsidies.

Great strides were made in public education, at the primary and, to a lesser extent, at the secondary levels. Post-secondary education continued, however, to remain largely off limits to Aboriginal youth, notwithstanding its wide democratisation in Canada. It is in the public health and general welfare that the greatest headway was made. To put it succinctly, for both Canada as a whole and for Aboriginal peoples within it, the years since the end of World War II, saw the mercantile-turned-capitalist economy give way to a more generous, socially-conscious welfare economy with a wide assortment of social assistance programs. The advent of the welfare economy and the broad societal changes had two major demographic consequences, one expected, the other unexpected.

It is in the area of health that the expected consequences stand out most prominently. Prior to World War II one can speak of minimalist public health intervention: it was sporadic and reactive to crisis situations like epidemics and famines. According to Young (1988), the emphasis was on medical relief rather than on the provision of comprehensive health services. After the war, however, one can speak of massive government intervention in public health. 


\section{Aboriginal Population of Canada: \\ Growth Dynamics under Conditions of Encounter of Civilisations}

The Aboriginal peoples entered the epidemiological transition that combined both preventive and curative medicine. The single most important post-war event in the history of medicine was the successful use of antibiotics against infectious diseases. Tuberculosis, the last of the many deadly epidemics which plagued the Aboriginal peoples, took a dramatic relapse. In the 1950s it was nearly eradicated, thanks to antibiotics.

Predictably from then on there was a dramatic reduction in mortality and commensurate gains in longevity. The pre-war rate of infant mortality, in the vicinity of 200 infant deaths under age one per 1,000 births, dropped to between 80 and 90 by 1960 and to 12 by 1990 . Correspondingly the expectation of life at birth rose from approximately 38 to 56 and to 69 years. The unexpected by-product of economic and health progress was an increase in the reproductive performance. I am saying 'unexpected' because, generally, modernisation brings about a reduction in fertility. Modernisation and demographic transition from high traditional to low modern fertility typically go hand-in-hand. So what caused the Aboriginal peoples to depart from the predictable path?

The mere fact that almost all deliveries were henceforth taking place in the maternity wards of hospitals or local health units, under the supervision of qualified medical personnel, coupled with many mothers undergoing pre- and post-natal check-ups, was bound to result in at least some reduction in miscarriages and stillbirths, primary and secondary sterility, and maternal deaths. As people gave up their nomadic mode of life for a sedentary and more comfortable one, pregnancy accidents may have decreased as well. But the major factor in the ferility increase was the massive switch from traditional, protracted breast-feeding to bottle-feeding (Romaniuc, 1981). Younger mothers either gave up breast-feeding completely or drastically reduced it. As a result, fecundity increased and birth intervals shortened. Fertility rates rose among younger generations in contrast to those of older, more traditionally-minded women.

The increase in natural fertility at the early stage of modernisation has been observed elsewhere in the world prior to the onset of the demographic transition. This writer has documented such a early modernisation-associated cycle of rise in natural fertility in Africa (Romaniuc, 1980). A host of biological and cultural factors, such as protracted lactation, prolonged post-partum sexual abstinence, sterility due to malnutrition and infections, particularly venereal, kept fertility well below the potential in the traditional societies. With the modernisation these fertility-depressing factors were either removed or weakened. Yet, birth control had not reached the critical level so as to the counter factors associated with early modernisation that were responsible for the increase in childbearing. The Aboriginal peoples, despite their opening up to modern influences, were apparently not yet prepared psychologically to embrace 
birth control practices within marriage on a significant scale. Nor did they have easy access to birth control like contraception or abortion.

The birth rate jumped from a pre-war time range of 40-42 to a range of 47-49 births per 1,000 population over the post-war period up to the mid-1960s. During the same period, the death rate dropped from about 20 deaths per 1,000 in 1945 to about 8 per 1,000 in 1970 . The two rates combined to produce an impressive average rate of natural growth that was slightly in excess of 3 percent per annum, a growth never experienced before nor likely to be matched in the future. The population rose from 166,000 in 1951 to 220,000 in 1961 , or an average annual increase of 2.9 percent. Thus the Aboriginal peoples entered a rapid demographic expansion that continues to the present. Though the fertility rate has since taken a deep cut, the demographic expansion is nevertheless expected to persist because of the growth momentum built into the age structure.

\section{Demographic Transition from Traditional High to Low Fertility}

The mid-sixties marked yet another turning point in the demographic evolution of Aboriginal peoples. While mortality continued to abate, in fact at an increasingly quicker tempo as economic and medical progress reached new heights, the birth rate took a nosedive from 48 in the early 1960s to about 30 births per 1,000 by 1980 .

The specific factors which triggered and sustained this sudden large-scale downward drift in fertility cannot be determined unambiguously. We know that it took place in a socio-economic context of rapid modernisation with all its manifestations, i.e. decline in infant mortality, gains in education, greater female labour force participation and aspirations for higher living standards. Faced with new opportunities and challenges brought forward by these developments, Native couples have responded as couples in modern societies typically respond by using a combination of strategies to limit their reproduction. At the beginning they were guided primarily by the same family considerations that were those of European-Canadian couples a century earlier when they first entered the demographic transition. Parity-related family limitation, to use the demographer's technical jargon, appears to have been the dominant mechanism during the very early stages of demographic transition. In recent years the trend to begin bearing children at a later age while stopping earlier, as well as a longer pause taken between pregnancies, could be indicative of the broadening grounds of birth control to accommodate both family size (parity) and timing considerations (Romaniuc, 1987). Thereby a more advanced stage of fertility transition has been entered. All these strategies had to take 


\section{Aboriginal Population of Canada: \\ Growth Dynamics under Conditions of Encounter of Civilisations}

effect for this scale of fertility reduction to have occurred in such a strikingly short time.

It is worth noting that this near-free-fall of the birth rate gave way to a marked slowdown in the 1980s, and even to what was apparently a short-lived reversal. Is this a midway slowdown, observed in a few other populations, undergoing demographic transition? How can it be explained? It might well be argued that Aboriginal citizenry trails its Canadian counterpart by a considerable margin on major scores of socio-economic development (see Table 1), and that by the same token it has not reached the developmental 'critical threshold' necessary to sustain the declining path of fertility. As appealing as the concept of 'critical threshold' may be, it remains rather illusive to theoretical rationalisation and empirical testing. The quest for a more rewarding explanation compels us to look into the Natives' existential conditions, such as culture of poverty, dependency syndrome, welfare, and the residual natalist subculture, and, beyond, into their ethos and value system. This is indeed what we will do in the next section.

\section{Contemporary Demographic Picture}

What is the Aboriginal peoples' demographic situation as they enter the new Millennium? To answer this question, we shall first examine their current and emerging reproductive patterns, then their population growth, and finally their settlement patterns. (For a broader contemporary demographic and socioeconomic profile of Aboriginal peoples refer to an earlier article published in this Journal by Russel Lawrence Barsh, 1994)

\section{Reproductive Patterns}

As we have seen Aboriginal peoples are well past the midway in their demographic transition. It took some 25 years to reach in the early 1990 s about 2.5 children per woman (all groups combined); this figure is down from about 6 in the mid-1960s. There are, however, significant inter-group differences in both the levels and the tempo of fertility decline, as shown in Tables 2. Inuit and Reserve Indians hold the upper hand with a total fertility rate of 4.3 and 3.8 respectively, while Métis and Non-status Indians inch closer to Canadian ebbs with a total fertility rate of about 2.5 or less. This configuration of Aboriginal groups' fertility is not surprising. Because of their socio-political status and their relative social and geographical isolation from main stream society, the Inuit and Indians on reserves have managed to preserve to a larger degree their

traditional family values. Interestingly, as Table 3 suggests, the status 
(registered) Indians on and off reserves seem to have stabilised their fertility standing at about 2.8 in the $1990 \mathrm{~s}$.

How do we explain the persistence of a fertility level that, although clearly diminishing, is still well above the national average? In attempting to offer some explanation, we shall go beyond the rather pedestrian approach based on the developmental indicators referred to earlier. I suggest we turn to two complementary explanations. One has to do with Aboriginal peoples' ethos, another with their existential conditions.

Table 1

Selected Socio-Economic Indicators for Native (N) and Non-Native (NN) Women, Based on the 1981 Census of Canada

\begin{tabular}{lccc}
\hline \multicolumn{1}{c}{ Indicator } & N & NN & N/NN \\
\hline $\begin{array}{l}\text { Average income of women } \\
15 \text { years and over }\end{array}$ & $\$ 6.073$ & $\$ 8,448$ & 0.72 \\
$\begin{array}{l}\text { Average income of } \\
\text { female lone-parent family }\end{array}$ & $\$ 8,194$ & $\$ 14,000$ & 0.59 \\
$\begin{array}{l}\text { Labour force participation } \\
\text { women 30-44 years old }\end{array}$ & $49.8 \%$ & $64.1 \%$ & 0.78 \\
$\begin{array}{l}\text { Women 15-29 years old with less } \\
\text { than Grade 9 }\end{array}$ & $25 \%$ & $6 \%$ & 4.17 \\
$\begin{array}{l}\text { Average number of children ever } \\
\text { born per 1000 ever-married women } \\
\text { in age groups: }\end{array}$ & & & \\
$\begin{array}{l}\text { 15-19 } \\
\text { 20-24 }\end{array}$ & 1,465 & 667 & 2.20 \\
\hline
\end{tabular}

Source: Pryor, E. T., Profile of Native Women: 1981 Census of Canada, Statistics Canada. Catalogue No. 98-X-54 (E), Ottawa, 1984. 


\section{Aboriginal Population of Canada: \\ Growth Dynamics under Conditions of Encounter of Civilisations}

It has cogently been argued (Gibbins and Ponting 1986; Frideres 1988) that Natives hold a cosmocentric view of the universe rather than the homocentric view of Western civilisation. Their's is a holistic perspective that focuses on the 'whole' rather than on the individual alone. Their actions are motivated mainly by the collective rather than the individual interest. They favour co-operation over competition. No wonder the spirit of the capillarity - the aspiration of having one's child move up the social ladder - a mind-set that is deemed to have been largely responsible for fertility decline among Western nations, was not part of the Natives' 'world-view'. Their political leadership has consistently opposed the federal government legislation that has emphasised individual equality and de-emphasised collective ethnic survival.

As to the existential conditions, a combination of related factors might explain the persistence of their relatively high fertility. The heavy reliance on the national welfare system, which in Native communities is closely associated with poverty, could be seen as a factor inhibiting the emergence of prudential attitudes in the matters of procreation. In fact some social assistance programs may act directly as incentives to procreation. The case in point is the welfare that benefits single mothers. Single motherhood and common-law unions are traditionally widespread among Aboriginal peoples, having existed well before the mania of paperless marriage engulfed all segments of Canadian society, but they are being reinforced by the material incentives that are given to unwed mothers. And there is yet another important existential condition that favours the propensity for higher childbearing: the Indian reservation remains the cradle where typical Indian traditions are preserved and cultivated. Some of these traditions are distinctly pro-family and pro-kinship. There is still a strong opposition to abortion and sterilisation. Pro-natalist culture as a survivalist strategy of the pre-modern society still seems to hold sway in traditional communities, according to Frank Trovato (1987).

\section{Health/Mortality}

With all their progress in health, Native peoples still have some way to go before achieving parity with their Canadian counterparts (for comparison see Table 4). They are still only midway in the epidemiological transition from predominantly infectious and parasitic diseases to degenerative and man-made causes of death (Trovato and Werner-Leonard 1991). While infectious and parasitic diseases associated with poverty still maintain their grip, a new wave of diseases associated with "civilisation" has taken hold. This combination of diseases account for their relatively high incidence of morbidity and mortality by age. 


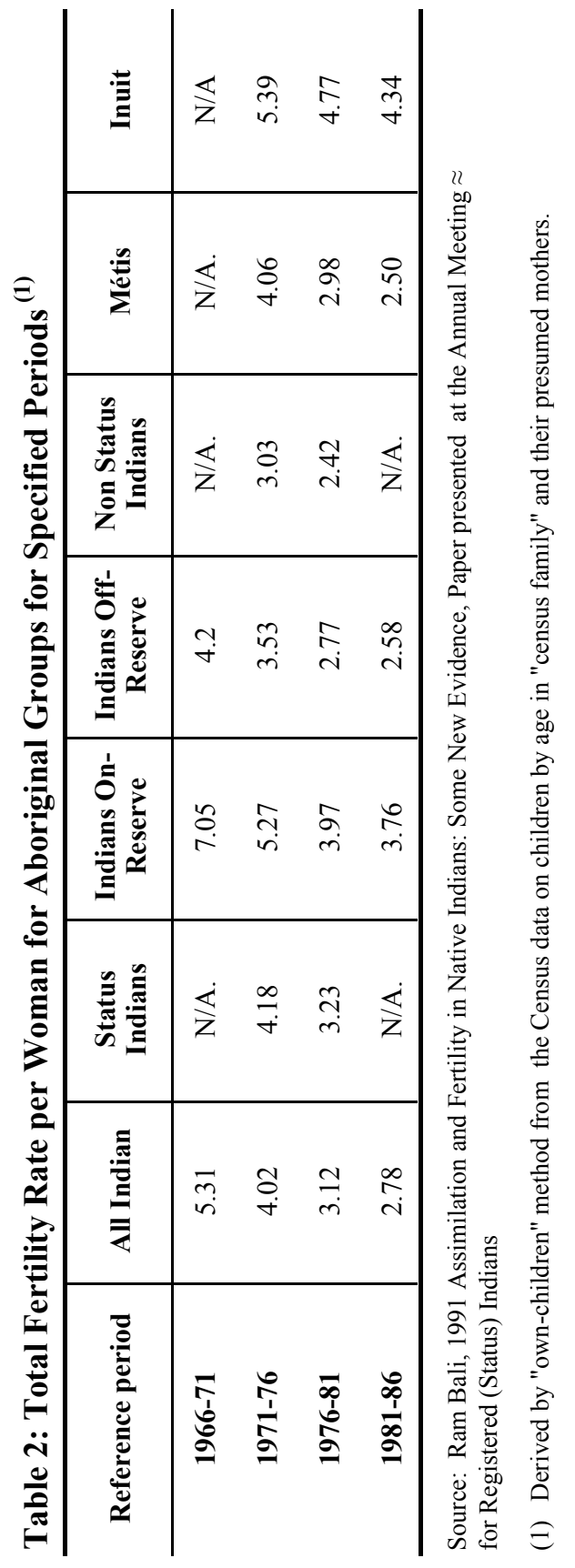


Aboriginal Population of Canada:

Growth Dynamics under Conditions of Encounter of Civilisations

Table 3

Total Fertility Rate (TFR) per Woman for Registered (Status) Indians

Only

for Canada, 1975 - 1996

\begin{tabular}{cccccc}
\hline Year & TFR & Year & TFR & Year & TFR \\
\hline $\mathbf{1 9 6 6 - 7 1}$ & 5.86 & $\mathbf{1 9 8 2}$ & 3.33 & $\mathbf{1 9 9 0}$ & 2.83 \\
$\mathbf{1 9 7 5}$ & 4.16 & $\mathbf{1 9 8 3}$ & 3.29 & $\mathbf{1 9 9 1}$ & 2.85 \\
$\mathbf{1 9 7 6}$ & 3.95 & $\mathbf{1 9 8 4}$ & 3.27 & $\mathbf{1 9 9 2}$ & 2.87 \\
$\mathbf{1 9 7 7}$ & 3.74 & $\mathbf{1 9 8 5}$ & 3.24 & $\mathbf{1 9 9 3}$ & 2.86 \\
$\mathbf{1 9 7 8}$ & 3.62 & $\mathbf{1 9 8 6}$ & 3.18 & $\mathbf{1 9 9 4}$ & 2.80 \\
$\mathbf{1 9 7 9}$ & 3.52 & $\mathbf{1 9 8 7}$ & 3.03 & $\mathbf{1 9 9 5}$ & 2.76 \\
$\mathbf{1 9 8 0}$ & 3.41 & $\mathbf{1 9 8 8}$ & 2.92 & $\mathbf{1 9 9 6}$ & 2.73 \\
$\mathbf{1 9 8 1}$ & 3.33 & $\mathbf{1 9 8 9}$ & 2.86 & & \\
\hline
\end{tabular}

Source: Demography Division, Statistics Canada.

Notes: Rates are calculated from the Indian Register and are adjusted for the late reporting and underreporting of births and deaths. Rate for the period 1966-71 is not adjusted for under and late reporting.

The relatively high level of the prevalent morbidity and its sex/age pattern mirror ecological and socio-economic conditions as well as culturally determined attitudes and behaviours. A significant component of mortality is made up of traumatic deaths due to accidents, violence and poisoning, as shown in Table 5. These deaths are partly environmental, partly poor men's afflictions that are attributable to such things as substandard housing and other ills that reflect the underprivileged status. Traumatic deaths, we have already seen, are not new phenomena. They have always been more or less prevalent throughout history, symbolising a kind of socio-cultural heritage and reflecting of ecological conditions. But modernity and resettlement into reservations may have added their deleterious stamp. Kunitz (1990) has argued that relatively high incidence of deaths due to violence may be related to the pattern of socialisation on reserves: "Among band-level peoples a primary method of conflict resolution was spatial dispersion rather than formal institutional controls of internalised self-control. When tribes are forced onto reservations, this mechanism can not 


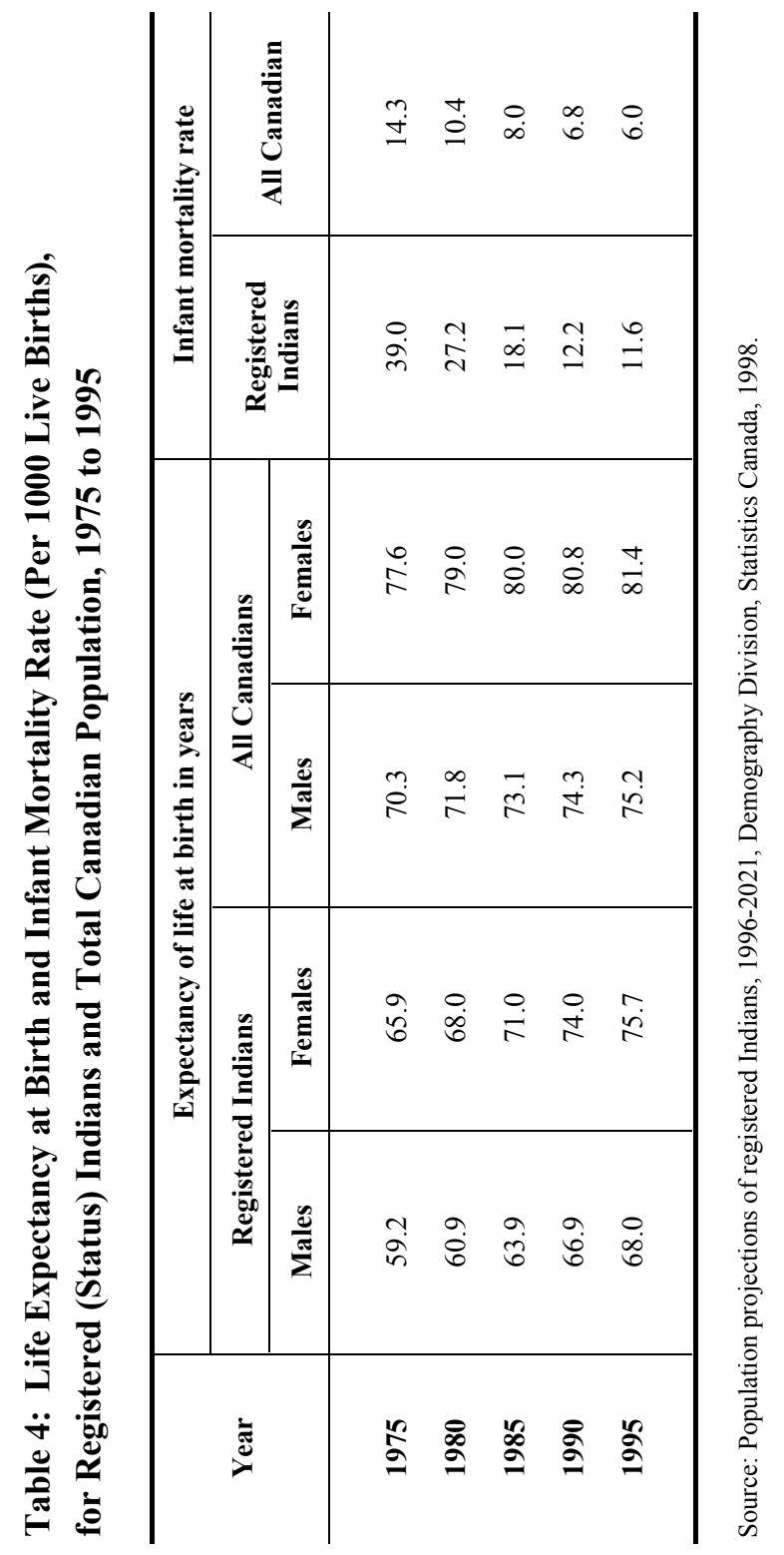




\section{Aboriginal Population of Canada: \\ Growth Dynamics under Conditions of Encounter of Civilisations}

operate adequately" (p. 660). The incidence of suicides (Table 6), well in excess of the levels prevalent in main-stream society, may indeed reflect the 'claustrophobia' of reserve life and the general malaise, tensions and stresses of a society facing the challenges of social change. Alcohol over-consumption, the growing use of substances among youngsters, and the traumatic effects, poignantly depicted by Anastasia Shkilnyk in her remarkable book (1985), remain a serious multifaceted health, social and political problem.

\section{Ethnic Mobility/Miscegenation}

A crucial variable in the growth of the Aboriginal population is inter-ethnic mobility. In a paper on the growth of Indigenous populations in Latin America, Chackiel and Peyser (1993) speak of a 'demographic paradox': even though these populations experience a high rate of natural increase, they can barely sustain their numbers. They ascribe this fact to the constant loss of cultural identity caused by miscegenation to the benefit of the dominant society. I have no knowledge of any attempt to quantify population gains and losses through this mechanism for Canada's Native peoples. On intuitive grounds, over the centuries one would expect the losses to outweigh the gains, as miscegenation and acculturation generally benefit the dominant society. The fact that identitybased counts in the 1991 Census represent only about 66 percent of the ancestrybased counts is in itself revealing ( Norris 1995 :151). But an overall assessment of gains and losses through ethnic mobility should be guarded, pending a thorough investigation of its mechanism and effects on Aboriginal peoples. The enfranchisement policy was not an unmitigated success for the assimilationists. In fact, it has been met with considerable resistance. In 1969 the plans for the abolition of the Indian Act, which was perceived by many Indians as a major safeguard of their rights and identity, met with "vociferous Indian opposition" (Gibbons and Ponting 1986: 23). Nor was the dominant society particularly forthcoming in embracing into its fold Natives prone to assimilation. Who is Aboriginal is also a matter of definition that happens to change over time (see below). The 1985 Bill C 31 - which removed the early gender discrimination whereby the children of an Indian woman married to a Canadian (including non-status Indian) automatically lost their Indian status is instrumental in some 120,000 being reinstated as status Indians between 1985 and 1996.

So far we have explored the demographic processes; next, we shall examine the outcome as gauged by the size and growth of population. 
Anatole Romaniuc

Table 5

Standardized ${ }^{1}$ Mortality Rates for Registered Indian Population and Total Canadian Populations, Average for 1978-81 and 1982-85

1978-1981

1982-1985

Disease Category

\begin{tabular}{ccccc} 
& Indian & Canada & Indian & Canada \\
\hline Circulatory & 313.8 & 344.2 & 315.0 & 301.2 \\
Injury/Poisoning & 278.1 & 64.3 & 218.2 & 55.0 \\
Neoplasm & 118.5 & 168.0 & 120.05 & 171.0 \\
Respiratory & 102.7 & 46.5 & 90.6 & 49.9 \\
Digestive System & 70.8 & 74.2 & 49.2 & 26.1 \\
Other causes & 201.3 & 74.2 & 174.4 & 73.9 \\
\hline
\end{tabular}

Source: Harris, J. and McCullough, Health Status Indicators from Vital Statistics, Native Indians, 1978-1986. Ottawa: Health and Welfare Canada, Medical Services Branch, 1988.

${ }^{1}$ Canada's total population by age for years 1980 and 1993 was used as base for the standardization.

\section{Population Size and Growth}

I shall preface my discussion of population numbers by remarks of a conceptual and definitional nature. It was a time when culture and biology coincided, so the identification of an Indigenous person was rather simple. There were no problems identifying an Indian or an Eskimo. As whites and reds came together, they gave birth to a new category of people, the Métis or Half-breed. Matters became increasingly confused with the passage of time when the post-war censuses introduced first the male ancestry as criteria for one's ethnicity, and then both male and female ancestries. In a bid to reproduce as fine a picture as possible of the country's ethnic and cultural mosaic, the 1996 Census to single ancestry added multiple ancestry. The question was asked: "To which ethnic or cultural group(s) did this person's ancestors belong?". The 1996 Census also asked a question about ethnic identity, as did the Aboriginal survey conducted as a follow-up to the 1991Census: "Is this person an Aboriginal person?" A more complete discussion of definitional changes of Aboriginal identification can be found in Goldmann and Siggner (1992). 
Aboriginal Population of Canada:

Growth Dynamics under Conditions of Encounter of Civilisations

Table 6

Suicide Rates by Age Group and Sex for Registered Indians and Total

Canada's Population (per 1,000 Population): 1989-1993

\begin{tabular}{ccccc}
\hline \multirow{2}{*}{ Age Group } & \multicolumn{2}{c}{ Canada } & \multicolumn{2}{l}{ Indians } \\
& Male & Female & Male & Female \\
\hline $0-14$ & 0 & 0 & 3.6 & 4.12 \\
$15-24$ & 24.1 & 4.5 & 125.7 & 35.0 \\
$25-34$ & 26.7 & 6.2 & 93.3 & 28.1 \\
$35-44$ & 26.0 & 7.8 & 50.3 & 18.8 \\
$45-54$ & 24.5 & 8.2 & 30.9 & 11.1 \\
$55-64$ & 23.9 & 6.5 & 24.7 & 9.1 \\
$65+$ & 24.3 & 5.4 & 25.2 & 2.4 \\
\hline
\end{tabular}

Source: Bobet, Ellen. 1990. Inequality in Health: A Comparison of Indian and Canadian Mortality Trends, Medical Services Branch, Health and Welfare Canada. Medical Service Branch Report 1996, Health and Welfare Canada.

According to the 1996 Census, 799,000 Canadians identified themselves as being Aboriginal, 554.3 as Indians, 210.2 as Métis, and 41.1 thousand as Inuit. Of self-identified Indians, 461.5 thousand were status (registered) and 92.8 thousand non-status. Altogether 1,103 thousand Canadians reported they were of Aboriginal ancestry, of whom 477.6 thousand clamed single ancestry and 624.3 multiple ancestry.

Rather than dealing with Aboriginal population in general, particularly as per its ancestry definition, a concept that is far too ambiguous and in some ways misleading (see Krotky 1995), I suggest we focus on one particularly important group of Indians - the status or registered Indians, that is those recognised as such under the Indian Act. By virtue of this Act, this group 
enjoys certain specified entitlements, including the right to keep a residence on the reserve. They elect their representatives to negotiate with the federal government over land claim settlements and many other rights under the treaties concluded with the Crown. They can be seen as de jury members, or if one wants, citizen of the First Nations. They are the core of the Indian ethnos and the mainstay of Indianess.

Table 7 brings together basic demographic parameters for the status Indians. A few comments are in order. Their crude birth rate has declined from 35 births per 1000 population in the 1960 s to 25 by the mid- 1990 s, but it is still twice that of Canada ( 12.2 in 1996). Although their mortality by age is higher, their crude death rate, due to the their much younger age structure, is lower than that of Canada's population - 5.0 against 7.1 per 1000 in 1996. The rate of natural increase fell from almost 3 early in the 1960s to 2 percent per annum in the 1990s, but this rate is still high compared to Canada's, which in 1996 was only 0.59 percent. Though Canada in recent years shows about one percent annual demographic increase, half of it is due to immigration. As time passes, the latter may be all that keeps Canada's population from declining.

There are peculiarities in the numerical increase of status Indians. Up until 1985, the net demographic increase closely parallels the natural increase. With the enactment of the 1985 Bill C-31, a new source of demographic growth has opened up. As already mentioned, about 120,000 Indian women and their offspring have been reinstated in their Indian status rights. But this demographic source is depleting because the eligibility pool for reinstatements is rapidly drying up. The great majority of Indians some forty years ago used to reside on the reserves; that proportion was still 85 percent in 1961 but fell to 58 by 1996.

The disproportionate growth of the Indians off-reserves since 1985 is due to the fact that reinstated women most often kept their off-reserve residences.

This rapid sketch of the most recent growth profile of Aboriginal peoples calls for two general remarks. On the Canadian scale, the numbers cited above are by no means trivial. The total Aboriginal population, by whatever definition, exceeds the population of any Maritime province and comes close to that of Manitoba or Saskatchewan. These numbers are the attainment of almost a century-long population growth, up from about one hundred thousand at the turn of the century. It has also been shown that this growth, sluggish in the four decades preceding World War II, picked up sharply thereafter. The second half of the 20th century will pass into the history of the First Nations as a golden age of demographic growth, unlikely to be emulated in the future. 


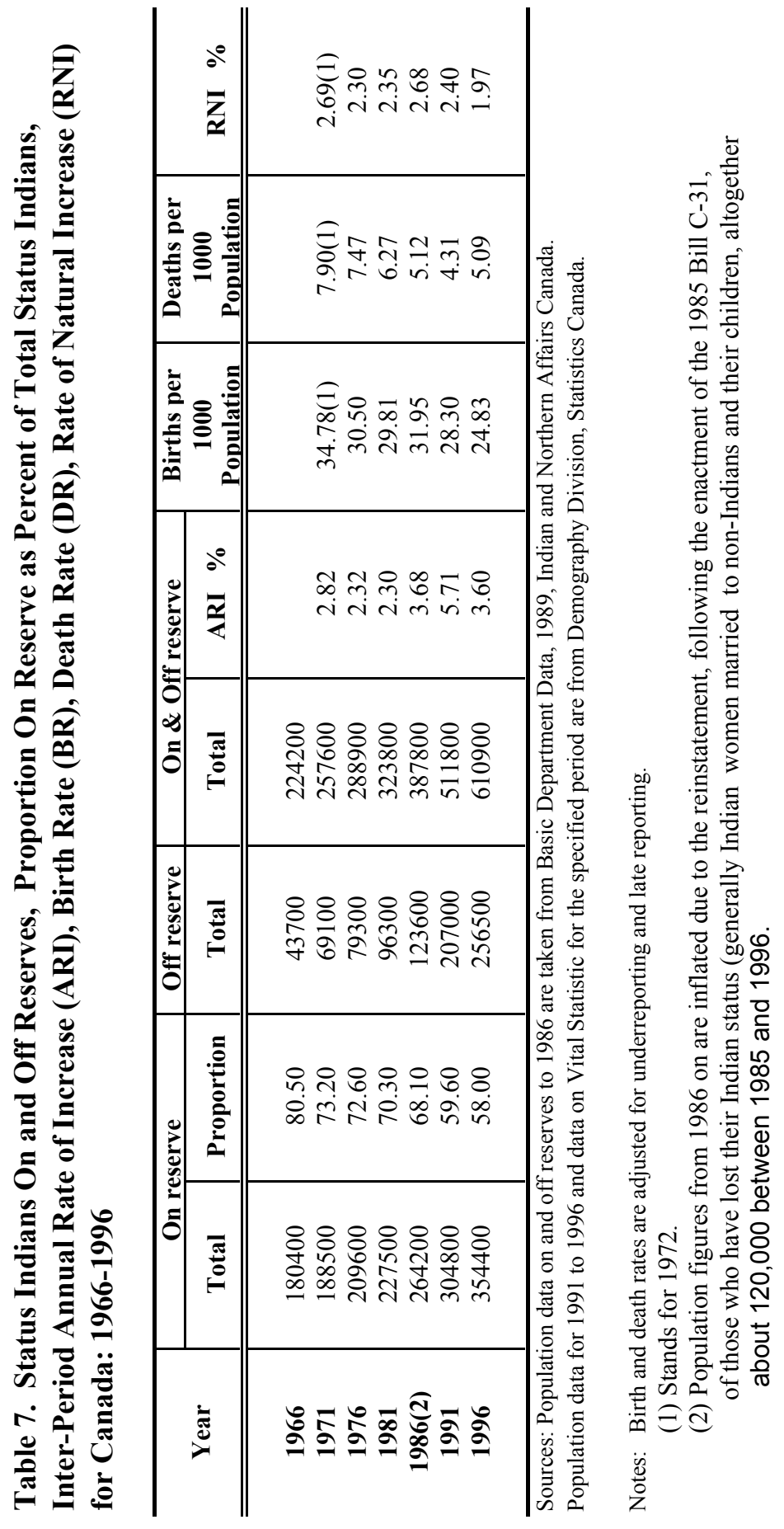


However, this growth in the second half of the 20th century, as remarkable as it no doubt is, has not made up for long-drawn periods of population losses in the past. There is nothing in it to parallel an almost uninterrupted growth in the number of French Canadians during the same period. An initial souche of just 5,000 or so French colonists, who landed during the 17th century and made Nouvelle-France their permanent home (Charbonneau et al, 1987), grew into a nation of six million. This feat is all the more remarkable given the long isolation of the French Canadians from the metropolis and losses throughout migration and assimilation. However, 'La revanche des berceaux' of Aboriginal peoples, unlike the one by French Canadians, was short-lived. As we have seen, the growth in recent years is due to natural growth as much as to the increments due to legal or census definitions.

\section{Settlement Patterns}

The First Nations of this country - the demographic surge described above notwithstanding - continue to suffer from two historically fundamental demographic weaknesses. One resides in their wide territorial dispersion. Isolated, single or clusters of, tribal settlements spread over the vastness of this country; they lacked strong political links and a cohesive institutional superstructure. This type of settlement pattern goes back deep into history. Colonisation did not much alter it, except that a new dimension, that of political and administrative fragmentation, was added to by writ of the government. The legal divide between Status and Non-status Indians, the Onreserve and Off-reserve dichotomy, and the Treaty and Non-treaty Indians are cases in point. The significant feature of this fragmentation is the administration of Aboriginal Affairs by the federal government through its Department of Indian Affairs and Northern Development to the level of the bands - entities that are small in number and weak in organisation.

The other Native demographic weakness, which grew out of European colonisation, is in their numerical weight in relation to the total population of Canada. Canadians who identify with any Native groups represent only 2.7 percent of the entire Canadian population, according to the 1996 Census. This percentage is 3.7 for those who claim single Aboriginal ancestry or a combination of Aboriginal and one or more other ethnic origins. However, there are significant regional variations: only about one percent in the Atlantic provinces, Quebec and Ontario, three in British Columbia and four in Alberta, nine in Manitoba and Saskatchewan, and 16 percent in the Yukon. It is in the Northwest Territories that Native groups constitute an indisputable majority of 62 percent. 


\section{Aboriginal Population of Canada: \\ Growth Dynamics under Conditions of Encounter of Civilisations}

So much for the present. We shall turn next to the future. What is in store for the First Nations as they step into the 21 st Century? At this point, I shall indulge in mixing demography with a bit of politics, and turn from descriptive to prescriptive demography.

\section{A Glimpse into the Future: Prospects and Challenges}

As we step into new century, we shall expect growth momentum of Aboriginal population to continue for a good while. By 2016, it may reach a range of 1.2 to 1.3 million, as per identity definition, up from 720,600 persons in 1991; and a range of 1.5 to 1.7 million, as per ancestry (single and multiple) definition, up from 1.1 million, according to Statistics Canada projections compiled by Mary Jane Norris (1995). These projections are conditional projections; that is, they hold true to the extent that the underlying assumptions hold true. Yet, as the history has time and again demonstrated such projections more often than not miss the target. Mortality and a fortiori fertility are difficult to forecast. The inter-ethnic mobility makes any forecast problematic. The legalistic and definitional determinations of one's ethnicity are elusive to any prognostication. Identity in general pose problems of analysis and interpretation as Philip Kreager (1997) has aptly demonstrated.

Rather than agonising about future numbers, I have chosen to devote the remainder of this paper to thoughts on the demographic and political environment in which Canada's Aboriginal peoples are likely to evolve henceforth. In their struggle to assert their pre-eminence as the first inhabitants of this country, they will have to contend with and overcome a score of problems. Some are rooted in history; others stem from federal government policies and forces operating nationally. I shall confine myself to the challenges ahead that are demographically-driven, and which are likely to alter the dynamics of Aboriginal body politics.

To begin, the historic demographic weaknesses referred to earlier - the territorial dispersal and political fragmentation along with their relatively modest numbers - present many challenges. In an age of electronic communication it is possible to overcome distance and bring communities closer. The greatest challenge, however, is political. How to overcome not only geographic barriers but more importantly cultural diversity and political factionalism are questions best left to the politicians to ponder, who have been doing so since the idea of Aboriginal self-government was brought to the fore of national political debate. The revival of historical entities that share common cultural affinities may be one of the policy options. This would infuse historical and cultural content back into the unification process which the policies of assimilation and fragmentation tend to 
Anatole Romaniuc

pre-empt.

Central to the future of the Aboriginal peoples is the status of the reserves. It is doubtful that Indians can survive as a political and cultural entity for long without reference to a territory, be it only a micro-territory. The reservation is the land base where geography, biology and culture meet to preserve and perpetuate the Indian ethnos. It is here that they best preserve their native customs and language. Whereas generally only three in ten Aboriginal individuals can carry through a conversation in their native language, 56 percent of reserve inhabitants can do so, according to the 1996 Census. Yet the reservation's very existence in the long run stands to be challenged by the forces of modernity. Vital to the reserves' sustainable development and selfgovernment is a healthy economy. "Most of the Indian leaders consider that a reserve-based economy is an essential constituent of self-government" (Boldt, 994: 230). But can such an economy be built, given the serious financial and entrepreneurial limitations, the geographic isolation and the small size of the reserves? Can the state and the private sectors generate enough local employment opportunities to meet the needs of a mounting number of youths and adults and thus avert a growing Aboriginal proletariat from fading away into the urban and industrial centres of the south; can it prevent its educated youth from being assimilated into the dominant society? The alternative - having to cope with a sizeable body of unemployed driven to despair on the reserves - is not an option one wishes to contemplate.

Any policy that is directed at strengthening the Aboriginal peoples' position in Confederation ought to recognise the uniqueness of the North. Their preponderance in the remote North, namely in the Northwest Territory (and their sizeable proportion in Yukon), has potentially important political ramifications. It is here that they stand the best chance of forming a politico-administrative territorial entity and enjoying a broad power structure of self-government on par with other provinces. The special status recently acquired by the territory Nunavut in the Arctic may be a step in that direction (see, Légaré, 1998). Will the Aboriginal peoples of the North succeed where Louis Riel in his bid for an Aboriginal autonomous territory failed more than a century ago? [The reference is made to Louis Riel's rebellion in 1870 and 1885 , which was an attempt to create a semi-autonomous territorial entity in lieu of the defunct Hudson Bay Company's Northwest territory (Stanley, 1960)]. The future will tell. To all intents and purposes, the North remains for the First Nations strategically an important bastion of power.

When demographers speak of growth, they have numbers, quantity, in mind. And that is rightly so. Numbers matter a great deal, particularly in a democratic political setting. But there is also quality. In this respect Native peoples stand to gain much. Healthier, better-educated and more productive individuals can make up, to some extent, for their shortfalls in numbers. In this long drawn-out 


\section{Aboriginal Population of Canada: \\ Growth Dynamics under Conditions of Encounter of Civilisations}

encounter of European and Aboriginal civilisations, the demographic quality cannot be overstated for the First Nations to assume the pre-eminent place they are entitled to by the sheer weight of history.

Society's renewal, as a cultural and demographic entity, is clearly rooted in childbearing. Yet there is little ground for optimism on this score. Unless the Aboriginal peoples are an exception to what appears to be universal tendency towards ever-lower reproductive norms as societies undergo modernisation, their fertility rate will settle somewhere below the replacement level probably sooner than later. They will join the growing number of nations which no longer reproduce themselves. This is where Canada is now. However, Canada has a leverage unavailable to them - immigration.

The Aboriginal peoples' future cannot be divorced from what appears to be in store for Canada as a whole. The commitment of Canada's federal government to the twin policies of sustaining population growth at one percent per annum, and erecting a multicultural society, by way of ever-increasing immigration favouring diversity, is bound to have consequences of historical proportions for Canada and its Aboriginal peoples. Two questions follow from these policies that are worthy of being weighed by the Aboriginal élite.

What will be the place of the First Nations in this emerging multicultural society which is assertively supplanting the order that has prevailed historically, the Canada of "the two founding nations plus Aboriginal peoples"? Over the four centuries of cohabitation with the British and French, institutional and political accommodations have been worked out, by no means fully satisfactory, which have so far ensured for Aboriginal peoples a unique place in Confederation. With the radical about-face in the Canadian immigration policy, there is for them a quantum leap from a historically established political setting of mutual accommodation to the uncharted waters of an emerging multicultural society.

The second question is how the policy of immigration-sustained growth of Canada's population is likely to affect in the long run the Aboriginal settlement patterns and treaty rights over land. The encroachment on Natives' land, or land they can claim on historical grounds, is expected to continue and even worsen as result of mounting population pressure. The stakes for eventual land compensation stand to increase, while the space available for traditional native activities (hunting, fishing) is expected to shrink, as will the landmass available for their potential demographic expansion in the future. On the other hand, while their population is expected to grow for a while, a one-percent growth per annum is unlikely to be sustained long enough to keep pace with Canada's population growth. The Aboriginal population will be dwarfed in relation to the 
ever-growing Canadian population, and in the long run will be marginalised to the point of becoming irrelevant as a political force. Inescapably, then, immigration policy presents itself to Canadian Aboriginal leaders as an issue of paramount importance.

Such are, it seems, grosso-modo, the demographically-driven issues that the First Nations of Canada are most likely to confront in this new century. If the future cannot be predicted, the future can be made. This sounds paradoxical only if we discount the role of human volition in social processes. Even though the First Nations are not the chief players, the overriding force in shaping Canada's destiny, they can make a difference.

I have tried to retrace the broad strides of the Canadian Aboriginal peoples' demographic history with a Janus-like approach - one eye turned to the past, the other to the future. To be life-giving, history must be forward-looking. No one can turn back the clock and retrieve what has been lost in the mazes of history, however great the nostalgia for the days gone-by may be. It would be fitting to conclude with words borrowed from Thomas Sowell, the author of Conquests and Cultures, the third book of his monumental Trilogy, who delves into the past of the Western Hemisphere's Indians and other great world cultures: "What is clear is that their [Indians] world was irretrievably shattered biologically, militarily, socially, and politically - and that their fate would henceforth be determined by how well they evolved new ways of dealing with a radically different and ever-changing reality around them" (1999:328).

\section{Acknowledgements:}

The author is grateful to the three anonymous referees for their constructive most helpful criticism of the original manuscript. Editorial assistance by Kelly Gadzala and Lara Romaniuc is graciously acknowledged. Any paper' shortcomings are author's responsibility.

Reprinted with permission of the editor of Canadian Journal of Native Studies. This article appeared in Volume 20, Number 1 (2000) of Canadian Journal of Native Studies. 
Aboriginal Population of Canada:

Growth Dynamics under Conditions of Encounter of Civilisations

\section{End Notes:}

1. Perhaps the most reliable work of this kind is the "Trois Siècles de depopulation aménndienne" (see reference) by Professor Hubert Charbonneau. It contains a critical evaluation of the historical estimates of Aboriginal populations of Canada for the early contact period.

The present paper is an expended version of a paper the author has presented at the 1995 Symposium of the Federation of Canadian Demographers, Towards the XXI Century: Emerging Socio-demographic Trends and Policy Issues in Canada, Ottawa.

2. A review of the estimation of the Aboriginal population in the Western Hemisphere is provided by Henry F. Dobyns, 1966 (see reference).

3. Many relevant observations are contained in The Jesuit Relations and Allied Documents, and in the memoirs of such explorers as Samuel de Champlain, Chevalier de La Salle, Alexander Mackenzie (see references) and many other. Also of interest is Des Indians du Canada à I'epoque de la colonisation française, R. Douville et J.D. Cassanova, Hachette.

4. The absence of the epidemics which recurrently swept over the Old World and took a heavy toll on its populations sets the New World apart in respect to morbidity causes. This perceived absence of a wide range of Old World epidemics - which as we have seen brought so much devastation to the Natives in the wake of the coming of the Europeans-led some students to question whether mortality amongst Western Hemisphere inhabitants was that high in pre-contact times.

\section{References:}

Abbott, John S.C. 1898. Chevalier de La Salle and his Companions. New York: Dodd, Mead and Company.

Balikci, Asen 1972. Female Infanticide on the Arctic Coast, in Mark Nagler (ed.), Perspectives on the North American Indians. pp. 176-189. Toronto: McClelland and Steward.

Barsh, Russel Lawrence 1994. Canada's Aboriginal Peoples: Social Integration or Disintegration The Canadian Journal of Native Studies, Vol. XIV, No 1. 
Anatole Romaniuc

Bobrick, Benson 1992. East of the Sun: The Epic Conquest and Tragic History of Siberia. New York: Henry Holt and Company.

Boldt, Menno 1993. Surviving as Indians: The Challenge of Self-Government. Toronto: University of Toronto Press.

Bone, Robert M. 1992. The Geography of the Canadian North - Issues and Challenges. Toronto: Oxford University Press

Burpee, Lawrence (Ed.) 1927. La Vérendrye, Journals and Letters of Pierre Gaultie d Varennes Sieur de la Vérendrye and his son. Toronto.

Byrne, P.E. 1927. The Red Man's Last Stand. London.

Chackiel Juan and Peyser Alexia 1993. Indigenous Population from Latin America National Censuses, Paper presented at the Population Conference. Montreal: International Union for Scientific Study of Population (IUSSP).

Charbonneau, Hubert 1984. Trois siècles de dépopulation amérindienne, in Louise Normandeau et Victor Piché (eds.) Les populations amérindiennes et Inuit du Canada, pp. 28-48. Montreal: Les presses de l'Université de Montréal.

Charbonneau, Hubert et al 1987. Naissance d'une population - Les Français établis au Canada au XVIIe siècle. Montréal: Presses de l'Université de Montréal.

Cook, Noble David 1998. Born to Die, Disease and New World Conquest, 1492-1650. Cambridge: University Press.

Dickason, Olive Patricia 1992. Canada's First Nations, A history of Founding Peoples from Earliest Times. Toronto : McClelland and Stewart Inc.

Dion, Joseph F. 1979. My Tribe - The Crees. Calgary: Glenbow Museum.

Dobyns, Henry F. 1966. Estimating Aboriginal American Population: An Appraisal of Techniques with a New Hemispheric Estimate, Current Anthropology, 7(4): 395-416.

Driver, H.E. and W.C. Massy 1957. Comparative studies in North America Indians. Philadelphia : The American Philosophical Society.

Dumont, Jean (ed.). 1962. Les voyages de Samuel de Champlain. Montréal: Les amis de l'histoire. 
Aboriginal Population of Canada:

Growth Dynamics under Conditions of Encounter of Civilisations

Douville R. et J.-D. Casanova 1964. La vie authochtonne à l'époque de la colonisation française. Paris: Hachette.

Farb, Peter 1972. Les Indiens: essai sur l'évolution des sociétés humaines. Paris: Editions du Seuil.

Frideres, James S. 1988. Native Peoples in Canada, Contemporary Conflicts. Scarborough: Prentice-Hall Canada.

Gibbins, Roger and Rick, J. Ponting 1986. Arduous Journey - Canadian Indians and Decolonization, J. Rick Ponting (ed.). Toronto: McClelland and Steward.

Goldmann, Gustave and Andrew Siggner. 1992. Statistical Concept of Aboriginal People and Factors Affecting the Counts in the Census and the Aboriginal Peoples Survey, in Towards the XXIst Century: Emerging Socio-Demographic Trends and Policy Issues in Canada. Ottawa: Federation of Canadian Demographers.

Grey, Alan 1990. A Matter of Life and Death: Contemporary Aboriginal Mortality. Canberra: Aboriginal Study Press.

Heagerty, John.J. 1928. Four Centuries of Medical History in Canada. Vol. I . Toronto: Macmillan.

Henry, Alexander (The Elder) 1809. Travels and Adventures in Canada and the Indian Territories between the Years 1760 and 1776. New York.

Innis, Harold A. 1910. The Fur Trade in Canada. New Haven.

Jenness, Diamond 1977. The Indians of Canada. Toronto: University of Toronto Press.

Kellogg, Louise Phelps (ed.) 1917.Early Narratives of the Northwest 16341699. New York: Charles Scribner's Sons.

Kreager, Philip 1997. Population and Identity, in D.I. Kertzen and T. Fricke (eds.), Anthropological Demography, pp. 139-174. Chicago: Chicago University Press.

Kroeber, A. L.1939.Cultural and Natural Area of Native America. Berkeley: University of California Press. 
Anatole Romaniuc

Krotki, Karol J. 1995. The Eight Million Artificial Canadians, their Future and Related Policies, Towards the XXIst Century: Emerging SocioDemographic Trends and Policy Issues in Canada. Ottawa: Federation of Canadian Demographers.

Kunitz, Stephen J. 1990. Public Policy and Mortality among Indigenous Populations of North America and Australasia, Population and Development Review, 16(4): 647-672

Légaré, André 1998. An Assessment of Recent Political Development in Nunavut: The Challenges and Dilemmas of Inuit Self-government, The Canadian Journal of Native Studies, Vol. XVIII, No 2, pp. 271-300.

Mackenzie, Alexander 1911. Voyages from Montreal through the Continent of North America to the Frozen and Pacific Oceans In 1789 and 1793, Two Volumes. Toronto: The Courier Press.

Mealing, S.R (ed.) 1963. The Jesuit Relations and Allied Documents. The Carleton Library No. 7. Toronto: McClelland and Steward.

Mooney ,James 1928. Washington: The Smithsonian Institution, Vol. LXXX, No 7.

Morrison Bruce R. and C. Roderick Wilson 1995. Native Peoples: The Canadian Experience. Toronto: McClelland \& Stewart Inc.

Nielsen Marianne O. and Robert A. Silverman 1996. Native Americans, Crime, and Justice. WestviewPress.

Norris, Mary Jane 1995. Projections of Aboriginal Populations in Canada, 1991-2016: Trends and Issues. Towards the XXIst Century: Emerging Socio-demographic Trends and Policy Issues in Canada, pp. 251-263. Ottawa: Federation of Canadian Demographers.

Pool, Ian 1991. Te Iwi Maori: New Zealand Population Past, Present and Projected. Auckland, NZ: Auckland University Press.

Price, John A. 1979. Indians of Canada, Cultural Dynamics. Scarborough Ontario: Prentice-Hall of Canada.

Ram, Bali 1991. Assimilation and Fertility of Native Indians: Some New Evidence. Paper presented at the Annual Meeting of the Canadian Population Society, in Kingston. 
Aboriginal Population of Canada:

Growth Dynamics under Conditions of Encounter of Civilisations

Ray, A. J. 1974. Indians in the Fur Trade: Their Role as Trappers, Hunters and Middlemen in the Lands Southwest of Hudson Bay, 1660-1870. Toronto: University of Toronto Press.

Roe, Frank Gilbert 1951. The Indian and the Hors. Norman: University Oklahoma Press.

Roe, Frank Gilbert 1955. The North American Buffalo a Critical Study of the Species in itsWild State Toronto: University of Toronto Press.

Romaniuc, Anatole 1981. Increase in Natural Fertility During the Early Stages of Modernisation: Evidence from an African Case Study, Zaire. Population Studies, Vol. 34, No 2: 293 - 31.

Romaniuc, Anatole 1981. Increase in Natural Fertility During the Early Stages of Modernisation: Canadian Indians Case Study, Demography, 18 (2): 157-172.

Romaniuc, Anatole 1986. Transition from Traditional High to Modern Low Fertility: Canadian Aboriginals, Canadian Studies in Population, 14(1): 69-88.

Sagard, Gabriel 1969. Le grand voyage au pays des Hurons. Montréal: Les amis de l'histoire.

Sametz, Z.W. 1964.The Progressive Integration of Man with the Environment in Camu P.,Weks E.P. and Sametz Z.W.(eds.), Economic Geography of Canada. Toronto: Macmillan.

Shkilnyk, Anastasia M. 1985. A Poison Stronger Than Love -The Destruction of an Ojibwa Community. New Haven: Yale University Press.

Sowell, Thomas 1999. Conquests and Cultures - A World View. BasicBooks.

Stanley, George, F. G. 1960. The Birth of Western Canada - A History of The Riel Rebellions. Toronto: Toronto University Press.

Talon, Jean 1676. Archives Coloniales Canada, corr. gén. 2, 1663-1706.

Thwaites, R.G. 1987. The Jesuits Relations and Allied Documents. Cleveland: The Burrows Brothers. 
Anatole Romaniuc

Thoronton, Russell 1987. American Indian Holocaust and Survival. A Population History since 1492. Norman: University of Oklahoma Press.

Trovato, Frank 1987. A Macrosociological Analysis of Native Indian Fertility in Canada: 1961, 1971, and1981. Social Forces, 66(2): 463-485

Trovato, Frank and Werner-Leonard 1991. An Analysis of Native Mortality, Journal of Indigenous Studies, 2(1):1-15.

Vogel, Virgil J. 1970. American Indian Medicine, Norman: University of Oklahoma Press.

Wissler, Clark 1936. Population Changes Among the Northern Plains Indians, Yale University Publication in Anthropology, No. 1. Yale University Press.

Young, T.K. 1988. Health Care and Cultural Change: The Indian Experience the Central Subarctic. Toronto: Toronto University Press. 
Appendix Table A

Total Aboriginal Population and its Main Ethnic Groups (Indian, Métis And Inuit), Based on the National Censuses for Canada, 1871-1996

\begin{tabular}{|c|c|c|c|c|}
\hline Year & Total population & Indian & Métis (Half-breed) & Inuit (Eskimo) \\
\hline & & (in thousands) & & \\
\hline On contact & 300.0 & & & \\
\hline ( $16^{\text {th }}$ century) & & & & \\
\hline 1871 & 122.7 & & & \\
\hline 1881 & 121.9 & & & \\
\hline 1891 & n.a. & & & \\
\hline 1901 & 106.6 & & & \\
\hline 1911 & 113.8 & & & \\
\hline 1921 & 120.7 & & & \\
\hline 1931 & 132.9 & 122.9 & n.a. & 6.0 \\
\hline 1941 & 160.1 & 118.3 & 35.4 & 7.2 \\
\hline 1951 & 165.6 & 155.9 & n.a & 9.7 \\
\hline $1961(2)$ & 220.1 & 208.3 & n.a & 11.8 \\
\hline 1971 & 312.8 & 295.2 & n.a & 17.6 \\
\hline 1981(2a)(ancestry) & 491.5 & (3) & (3) & (3) \\
\hline Single response & 413.4 & 313.7 & 76.5 & 23.2 \\
\hline Multiple response & 78.1 & 26.3 & 49.6 & 2.2 \\
\hline $1986(4)$ & 756.4 & & & \\
\hline 1986 (ancestry) & 711.7 & (3) & (3) & (3) \\
\hline Single response & 373.3 & 286.2 & 59.7 & 27.3 \\
\hline Multiple response & 78.1 & 262.7 & 91.9 & 9.2 \\
\hline $1991(4)$ & 1084.1 & & & \\
\hline 1991 (ancestry) & 1002.7 & (3) & (3) & (3) \\
\hline Single response & 470.6 & 365.4 & 75.2 & 30.1 \\
\hline Multiple response & 532.1 & 418.6 & 137.5 & 19.2 \\
\hline Identity (5) & $632.2(720.6)$ & 460.7 & 135.3 & 36.2 \\
\hline 1996 (6)(ancestry) & $1,102.00$ & (3) & (3) & (3) \\
\hline Single response & 477.6 & 395.0 & 50.0 & 33.0 \\
\hline Multiple response & 624.3 & 473.0 & 171.0 & 17.0 \\
\hline Identity (5) & 799.0 & 554.3 & 210,2 & 41.1 \\
\hline
\end{tabular}

Sources and Notes: (1) Early contact period population figure is that estimated by Hubert Charbonneau (see text for estimation method and reference for source).

(2) Except for 1941, figures for 1871 to 1961 are census based counts, taken from Sametz (1965), Table 2.1, p.35. Figures prior to 1931 were adjusted by Sametz for territories which officially were not part of Canada or were not covered by the Census. Figure for 1941 is taken from Goldmann and Siggner (1995). The 1891 Census did not include a question on ethnic or racial origin. In the 1901 Census, Indians and Métis were grouped together in that census (see Sametz, Table 2:1)

(2a) Figures for 1981 to 1991 are census-based as per ancestry (single and multiple ancestry), taken from Goldman and Siggner (1995, Table 1.2).

(3)The single and multiple responses can only be added together for the total Aboriginal count. Multiple responses for any of the detailed categories may include double counting. For example, it is possible for a respondent to report that they have both Métis and Indian origins. In this case they would be included in both multiple counts, however, they would only be counted in the Total Aboriginal once.

(4) The 1986 and 1991 Census figures (highlighted) are adjusted for incompletely enumerated Indian reserves and for Census under-coverage.

(5) Self-identity based on the question, 'Is this person an Aboriginal person?', asked in 1996 Census and also in the 1991 post-Census Aboriginal Survey. For 1991 Census figure in bracket of Aboriginal self-identity is adjusted for incomplete enumeration. Included in the 1996 Census identity count are 19,220 persons who are registered Indians or members of Indian band or First Nations but who did not report identity.

(6) 1996 Census counts do not include incompletely enumerated reserves, nor are they adjusted for underreporting. 